\title{
HEAT TRANSFER MECHANISMS IN VERTICAL GREEN SYSTEMS AND ENERGY BALANCE EQUATIONS
}

\author{
F. CONVERTINO, G. VOX \& E. SCHETTINI \\ Department of Agricultural and Environmental Science - DISAAT - University of Bari, Bari, Italy.
}

\begin{abstract}
The use of vegetated vertical systems is a sustainable technology for improving the energy efficiency of buildings in cities in order to reduce the energy consumption for air conditioning in summer and to increase the thermal insulation in winter. Increasing urban green infrastructure (UGI) in a city can contribute to improve urban climate in summer reducing buildings surface temperature and urban air especially in Southern Europe. The application of vertical green systems requires the knowledge of the energy performance of the applied greenery system. The choice of the green facades depends on the local climate, water availability, building shape.

The presence of green facades affects the building microclimate all day, by reducing heat waves during the warm periods and heat losses from the building in the cold period.

The heat and mass transfer between the external environment, the green facades and the building surface determine the building microclimate. Solar radiation, long wave infrared radiation, convective heat transfer and evapotranspiration are the main mechanisms of heat transfer in a green façade.

The paper describes the main parameters concerning heat flow in green facades that can be used in simulation models for predicting temperatures in buildings using the external weather conditions as model inputs. The input parameters are: external air temperature and relative humidity, solar radiation, wind velocity and direction, plants and building characteristics.

The green facade was described by a schematic representation, four layers were defined: the green layer, the external surface of the building wall, the internal surface of the building wall, the air inside the building.

The energy balance was defined for each layer and all the terms involved in the energy exchange between the layers were defined as a function of the plant, the weather conditions and the constructive characteristics of the wall.

Keywords: convection, evapotranspiration, green facades, green walls, modelling, solar radiation, urban agriculture.
\end{abstract}

\section{INTRODUCTION}

Vertical greening systems are characterized by plants grown on buildings vertical surfaces. This kind of envelope technological solution has a very ancient history, dating back to Babylonians. Over time, the forms of vertical green systems have spread and have changed considerably. Literature is rich in an incredible variety of definitions of all the different types of vertical greening systems [1], [2]. The main difference is between green facades and green walls. Green facades are usually realized with climber plants covering the wall and rooted into the soil or in planter boxes. They can be distinguished into direct green facades, where plants are attached directly to the wall, and indirect green facades, characterized by the presence of a supporting system, such as continuous guides or modular trellises, to assist the upward growth of climbing plants, in this way creating a sort of second skin detached from the wall. Green walls are an alternative and most recent solution to vegetate the vertical walls. They are usually composed of a supporting element, a growing medium, plants and an irrigation system. Supporting elements can be lightweight and permeable screens in which plants are inserted individually (continuous living wall systems) or pre-cultivated modular panels (modular living wall systems) that already contain the growing medium and the irrigation system; they can be fixed directly to the wall or to a supporting frame. The panels or 
geotextile felts support plants development. Green walls rapidly create a uniform growth of a wider variety of plant species along large wall surfaces in high buildings [3], [4].

Nowadays, the spread of vertical greening systems is rising. This is due to the growing need of environmental sustainability. In fact, the use of green layers in buildings is a smart way to mitigate several environmental problems and to improve the quality of urban contexts. The advantages deriving from their use and diffusion are many and very remarkable, under various points of view and at different scales. Vertical green layers applied to building walls allow to reduce energy consumption for air conditioning, in summer, and to improve thermal insulation, in winter [3], [5]-[10]. Thus, green vertical systems can be used as a passive technology for enhancing the energy efficiency of buildings and for mitigating the frequency and magnitude of the heat events due to urban heat island (UHI). In comparison to the green roofs, the green vertical systems are the most suitable systems for greening dense urban areas because buildings with a high wall to roof ratio offer large surface areas available for retrofitting [12]. They reduce the ambient temperatures and improve human thermal comfort [4], [10], [11]. Green vertical systems function as a solar shading barrier reducing the heating of the external surface of the building during daytime and function as thermal barrier at nighttime [8], [13]. An important and additional benefit of this living screen, respect to no living ones, arises in relation to solar radiation. In fact, plants produce a cooling effect by intercepting the incident solar radiation; actually, plants partially reflect and partially use solar radiation for the biological activities such as evapotranspiration, photosynthesis, and storing it through the lymphatic system [5], [14]. Evapotranspiration leads to cooling the leaf and the temperature of the surroundings and consequently reduces the cooling load of the buildings [12], [14], [15]. The main advantages given by green vertical systems, in summer, are a lower external and internal surface temperature and an improved indoor thermal comfort [4], [5], [10], [11], [16], [17]. While, in winter, they are able to reduce energy demands for heating, by decreasing the wind velocity and by controlling heat losses [3]. In the functioning of vertical greening systems, significative aspects are the wall orientation and the specific characteristics of the greenery system used [13], [18]-[21]. Nevertheless, only few studies deal with the long-term thermal performance of these systems useful to assess suitable plant species and systems options [4], [5], [13]. Another critical aspect is the poor availability of simulation tools, specifically designed to describe and forecast the vertical green systems energy performance. Many authors use effective thermal resistance as a parameter to compare thermal benefit and characteristic of vertical green systems [22]-[24].

The study and the comprehension of the energy balance in vertical greening systems are essential to better understand, to make the most of the potential and to obtain the maximum benefit from their use. When working with living systems, the reaching of this objective is not so easy, because of the numerous and complex variables involved and because plants respond to environmental conditions in a very complicated way [25]. In the most recent literature the researchers' attention to this problem emerges. Some authors, concentrating on the reduction of the solar radiation on the wall behind the plant, focused on the leaf coverage and proposed a sort of shading or bioshading coefficient [26], [27]. However, although this is one of the most significative influence of the green canopy, it is necessary to evaluate all the other complex and determining processes, such as the radiative, the convective and the latent (i.e. the evapotranspiration) heat transfer. It is possible to find, in literature, different modelling approaches for the heat and mass exchanges, interesting, in particular, the vegetated layer: the big leaf, the dual leaf and the multi-layer canopy model, with an increasing complexity. It is also very common to find, in the models, the thermal-electrical analogy. Among the most recent studies' objectives, there is that to realize complete analytical models and to validate 
them by empirical measurements. Many attempts were made to describe the evapotranspiration process. Larsen et al. [25] proposed an energy balance equation for the foliage, in which the latent contribution derives from the well-known Penmann-Monteith (PM) equation, advised by FAO [28]. The authors considered a glazed façade, to point out the reduction in the direct solar radiation through the green wall. Malys et al. [29] proposed a hydrothermal model of vegetated walls, for the implementation in an urban microclimate simulation software, and compared simulation results with experimental data obtained for three green wall samples. Scarpa et al. [30] tried to predict the thermal behaviour of living walls, considering two kinds of living walls, one with grass and closed air cavity and another with vertical garden and open cavity. They used the PM equation and managed to deduce the crop coefficient (which distinguishes the considered crop from the hypothetical reference crop), considering the most correct equivalences with the FAO guide, which includes only agricultural species. Evapotranspiration was particularly analysed also by van de Wouw et al. [31]. They derived crop coefficient by comparing the reference crop evapotranspiration value, calculated through PM equation, with empirical data, obtained from an experimental setup, designed to monitor the changes in water contents. From these and other recent studies, a close connection between the solar radiation and the functioning of the vertical green systems clearly emerges. This work allows to point out this influence, as well as that of the other thermal contributions.

Therefore, in a vertical green system all the terms of the energy balance must be determined in the most effective way, even if the presence of the living component makes it not a simple task. Among the balance components, the most characteristic is the evapotranspiration, which deserves a particular attention.

To assess the actual effects of the green vertical systems, mathematical models are needed, also for their implementation in simulation software. This implies the necessity to increase the analytical modelling, still at an initial stage, together with the most common empirical approach.

This paper aims to investigate the heat flow mechanisms involved in green facades. Heat balance equations for the different layers, in which the system was schematized, were defined. The attention was focused, specifically, on the energy balance of the vegetate layer.

\section{MATERIALS AND METHODS}

The thermal exchange in the green facades occurs by convection, conduction and radiation heat transfer. The latent heat flux also contributes to the energy exchange; latent heat arises from the evapotranspiration that is a typical process of the plants. A schematic representation of the green facade is reported in Fig. 1 with the different heat fluxes existing in the system.

The green facade was described by means of energy balance equations corresponding to the different layers [32], [33]: the green layer ( $\mathrm{gl}$ ), the air gap between the green layer and the building external wall (ag), the external surface of the building wall (ew), the internal surface of the building wall (iw) and the air inside the building (ia). For each of these layers, the heat fluxes were modelled and a heat balance equation was written.

The system was simulated by means of a one-dimensional model, considering only the energy flux normal to the wall, thus neglecting the horizontal fluxes of energy.

\subsection{The energy balance equations}

The layers exchange energy by radiation in the solar wavelength range between 300 and 3000 $\mathrm{nm}(\mathrm{E})$ and in the longwave infrared (LWIR) range $>3 \mu \mathrm{m}(\mathrm{R})$, by convection $(\mathrm{CV})$, conduction $(C)$ and evapotranspiration $(\Phi)$; energy is also stored into the layers $(\mathrm{S})$. 

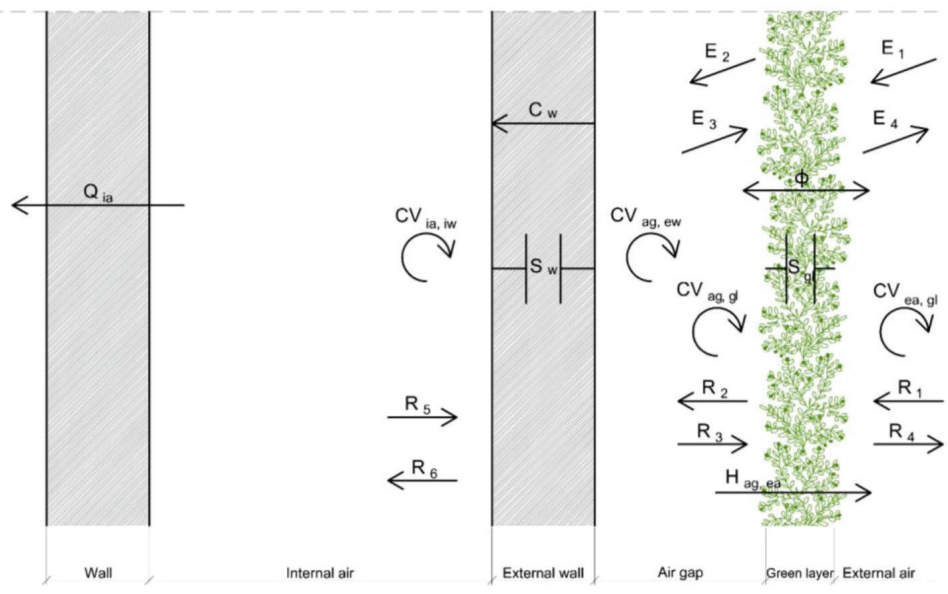

Figure 1: Schematic representation of the green facade and of the energy fluxes for each element.

An energy balance equation was written for each layer (Fig. 1).

The heat balance for the air inside the building is:

$$
C V_{i a, i w}-Q_{i a}=0
$$

The heat balance for the internal surface of the building wall is:

$$
\varepsilon_{i w} R_{5}-R_{6}-C V_{i a, i w}=0
$$

with:

$$
\begin{aligned}
& R_{5}=\varepsilon_{i r} \sigma T_{i r}^{4} \\
& R_{6}=\varepsilon_{i w} \sigma T_{i w}^{4}
\end{aligned}
$$

both calculated according to the Stefan-Boltzmann law.

The heat balance for the external surface of the building wall is:

$$
E_{2}-E_{3}+\varepsilon_{e w} R_{2}-R_{3}-C V_{a g, e w}-C_{w}-S_{w}=0
$$

The terms $\mathrm{C}_{\mathrm{w}}$ and $\mathrm{S}_{\mathrm{w}}$ express the contributes of heat conduction and storage into the first layer of the building external wall, respectively. Heat storage and conduction in the building wall were considered by using the Fourier's heat equation:

$$
\frac{\partial T}{\partial t}=D \frac{\partial^{2} T}{\partial z^{2}}
$$

The heat balance for the air of the gap is:

$$
C V_{a g, e w}-C V_{a g, g l}-H_{a g, e a}=0
$$


The term $H$ accounts for the heat exchanged by ventilation between the air in the gap and the external air.

The heat balance for the green layer is described by:

$$
E_{1}-E_{4}-E_{2}+E_{3}+\varepsilon_{g l}\left(R_{1}+R_{3}\right)-\left(R_{4}+R_{2}\right)+C V_{e a, g l}+C V_{a g, g l}+S_{g l}-\Phi=0
$$

The evapotranspiration term $(\Phi)$ is specific of the vegetation.

2.1.1 Energy exchange in the green layer

The attention is, here, focused on each term of the energy balance of eqn (8).

\section{Heat storage}

The heat storage in the green layer $\left(S_{g l}\right)$ was neglected, since the heat capacity of the vegetated layer is small compared to the other existing fluxes.

\section{Shortwave radiation}

$E_{1}$ is the solar radiation on a vertical surface, the other $E$ terms can be calculated by means of $E_{1}$, the green layer solar reflectivity $\left(\rho_{\mathrm{gl}}\right)$, transmissivity $\left(\tau_{\mathrm{gl}}\right)$ and absorptivity $\left(\alpha_{\mathrm{gl}}\right)$ and the external wall surface solar reflectivity $\left(\rho_{\text {ew }}\right)$ :

$$
\begin{gathered}
E_{2}=\tau_{g l} \cdot E_{1} \\
E_{3}=\rho_{e w} \cdot \tau_{g l} \cdot E_{1} \\
E_{4}=\rho_{g l} \cdot E_{1}
\end{gathered}
$$

The algebraic sum of the E terms gives the net solar radiation absorbed by the green layer.

\section{Longwave radiation}

The LWIR heat exchanges are:

$$
R_{1}=R_{\text {sky }}+R_{\text {ground }}
$$

$\mathrm{R}_{1}$ includes the flux of LWIR radiation coming from the sky $\left(\mathrm{R}_{\text {sky }}\right)$ and from the ground $\left(\mathrm{R}_{\text {ground }}\right)$ over the solid angle of sky and ground viewed by the green layer, respectively:

$$
\begin{gathered}
R_{\text {ground }}=\sigma \cdot F_{\text {ground }} \cdot T_{\text {ground }}^{4} \\
R_{s k y}=\sigma \cdot F_{s k y} \cdot T_{s k y}^{4}
\end{gathered}
$$

$\mathrm{R}_{\text {ground }}$ and $\mathrm{R}_{\text {sky }}$ are calculated in accordance with the Stefan-Boltzmann law; with:

$$
T_{s k y}=0.0552 \cdot T_{e a}^{1.5}
$$

calculated as suggested by Kindelan [33], in clear sky conditions.

The other $R$ contributes take into account the LWIR emission from the green layer $\left(R_{2}\right.$ and $\mathrm{R}_{4}$ ) and from the building external surface $\left(\mathrm{R}_{3}\right)$ :

$$
\begin{gathered}
R_{2}=R_{4}=\sigma \cdot \varepsilon_{g l} \cdot T_{g l}^{4} \\
R_{3}=\sigma \cdot \varepsilon_{e w} \cdot T_{e w}^{4}
\end{gathered}
$$




\section{Convection}

The convective heat exchange between the external air and the green layer was calculated according to Papadakis [34], using the Nusselt number for pure forced flow:

$$
C V_{e a, g l}=\rho_{a} \cdot C_{p a} \cdot\left(T_{e a}-T_{g l}\right) \cdot r_{e}^{-1}
$$

The convective heat flux between the air gap and the green layer is:

$$
C V_{a g, g l}=h_{a g} \cdot\left(T_{a g}-T_{g l}\right)
$$

\section{Evapotranspiration}

The latent heat transfer associated to the evapotranspiration process is calculated according to [34], [35]:

$$
\Phi=\rho_{a} \cdot C_{p a} \cdot\left(e_{s, g l}-e_{a}\right) \cdot \gamma^{-1} \cdot\left(r_{s}+r_{e}\right)^{-1}
$$

where $r_{s}$ is the stomatal (or internal) resistance and $r_{e}$ is the aerodynamic (or external) resistance.

\subsection{Application to experimental data}

The energy balance model was applied using the data collected in 2015 at the experimental centre of the University of Bari, where a green facade was realized. The wall was made as prototype of a commonly used vertical building closure in Mediterranean civil construction. The wall facing south was built using perforated bricks joined with mortar. Pandorea jasminoides variegated, evergreen climbing plant, was chosen as greenery vertical system component. A plant supporting structure made of an iron net was placed at a distance of 15 $\mathrm{cm}$ from the vertical wall. The experimental data were collected by means of a meteorological station consisting of a data logger (CR10X, Campbell, Logan, USA) and several sensors for measuring different climatic parameters. The data were measured with a frequency of $60 \mathrm{~s}$, averaged every $15 \mathrm{~min}$ and stored in the data logger. The solar radiation normal to the wall was measured using a pyranometer (model 8-48, Eppley Laboratory, Newport, RI, USA) in the wavelength range $0.3-3 \mu \mathrm{m}$. The external air temperature was measured by a Hygroclip-S3 sensor (Rotronic, Zurich, Switzerland). The temperature of the external plaster surfaces exposed to the solar radiation was measured using thermistors (Tecno.el s.r.l. Formello, Rome, Italy).

\section{RESULTS AND DISCUSSION}

The proposed mathematical model aims to simulate the energy behaviour of green facades in different boundary conditions. The model was applied in the case of the green facade realized at the experimental centre of the University of Bari. Two summer clear days characterized by a measured maximum vertical solar radiation equal to $399.2 \mathrm{~W} / \mathrm{m}^{2}$ (17 July 2015) and equal to $608.5 \mathrm{~W} / \mathrm{m}^{2}$ (17 September 2015) were considered.

Figures 2 and 3 show the results of the application of the model to the data recorded on 17 July 2015. Figure 2 shows the main contributes of sensible heat to the energy balance calculated for the green layer: net vertical solar radiation, net longwave radiation and convection; the measured temperature of the vegetation is also shown. The highest contribution to 


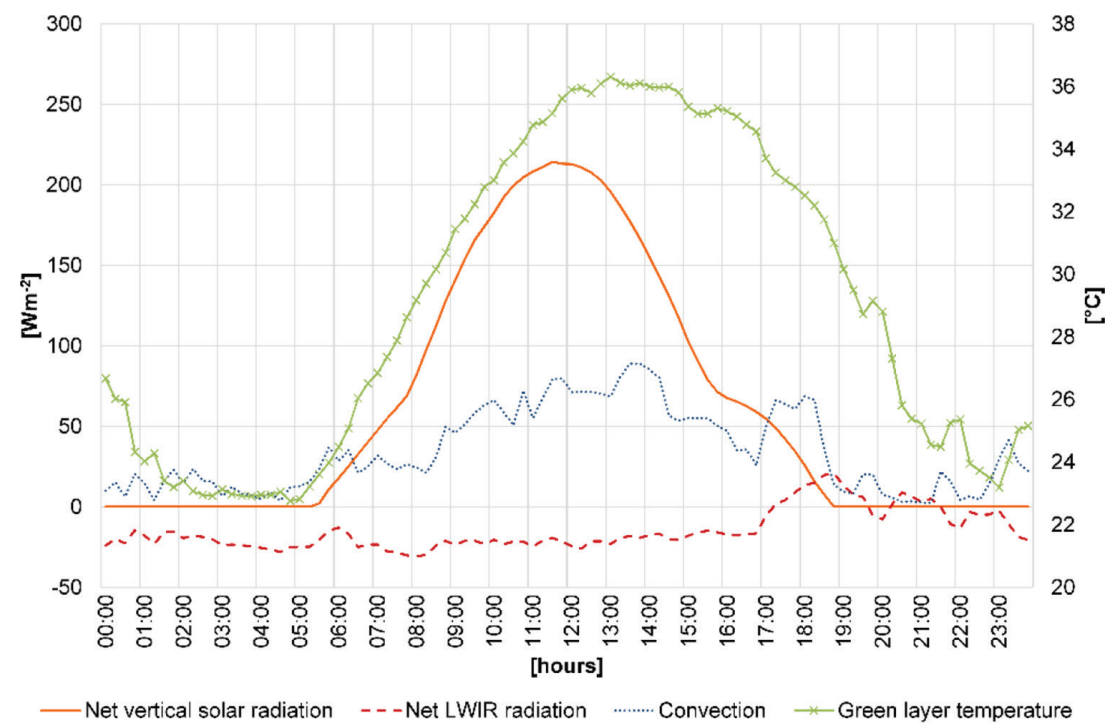

Figure 2: Net vertical solar radiation, net LWIR radiation and convection energy exchange for the green layer, measured green layer temperature (secondary axis), 17 July, 2015.

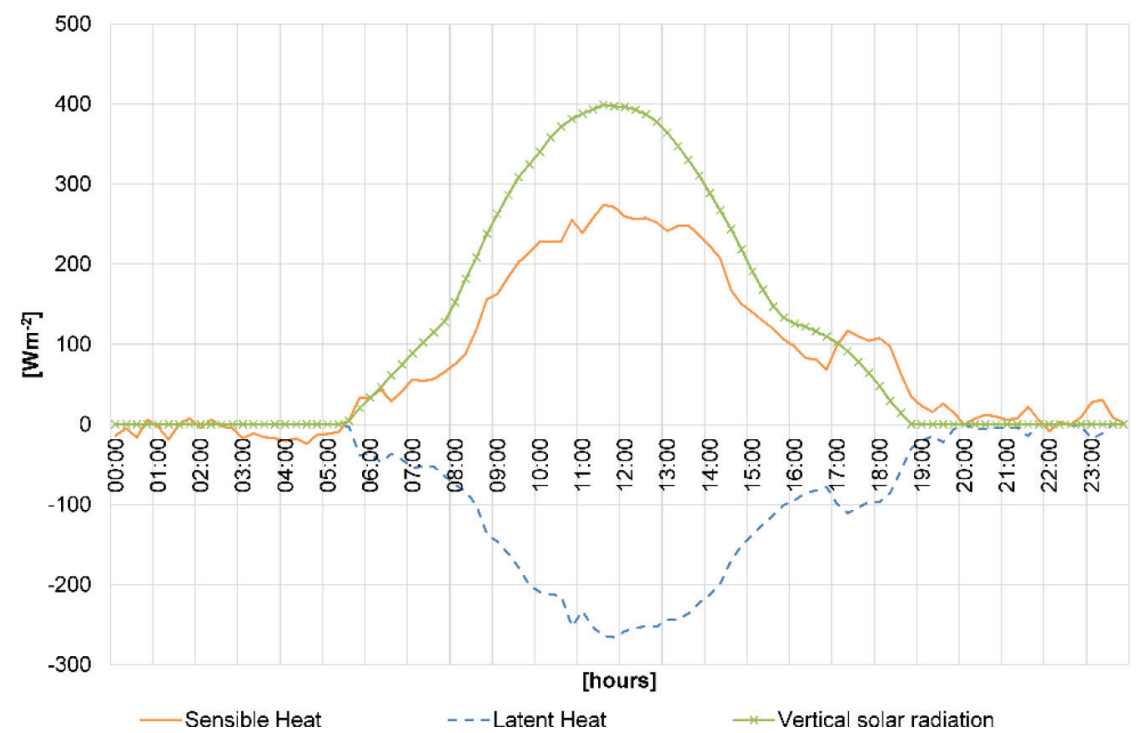

Figure 3: Sensible heat and latent heat exchange for the green layer, measured vertical solar radiation, 17 July, 2015.

the sensible heat absorbed by the vegetation is given by the shortwave radiation. The net LWIR radiation flux has generally negative values, so the green layer loses energy in this way. The convective heat transfer, always positive, has a jagged trend, because it is particularly influenced by the wind speed. 
Sensible heat and latent heat for the vegetation are plotted in Fig. 3. The sensible heat is the sum of all the radiative and convective contributes. The latent heat represents the quantity of energy lost by the vegetated layer through the evapotranspiration mechanism. There is a symmetry between the two curves that represent the energy input and output for the layer.

The maximum values of net vertical solar radiation, convection and latent heat, calculated for 17 July 2015 , were $214.3 \mathrm{~W} / \mathrm{m}^{2}, 88.0 \mathrm{~W} / \mathrm{m}^{2}$ and $265.8 \mathrm{~W} / \mathrm{m}^{2}$, respectively.

Similar results were pointed out applying the model to the data recorded on 17 September 2015 (Figs 4 and 5), with the exception of the convective heat transfer that was sometimes negative. The maximum values of net vertical solar radiation, convection and latent heat, calculated for 17 September 2015 were $326.7 \mathrm{~W} / \mathrm{m}^{2}, 106.5 \mathrm{~W} / \mathrm{m}^{2}$ and $344.7 \mathrm{~W} / \mathrm{m}^{2}$, respectively.

Shortwave radiative energy influences the evapotranspiration and then the latent heat flow (Figs 3 and 5). The solar term seems to be confirmed as the most decisive for latent exchange. Malys et al. [29] by comparing latent heat flux values between a sunny and a cloudy day, for green wall samples in Geneva (Switzerland), suggested that solar radiation is the most sensitive parameter in latent heat calculations. Hoelscher et al. [36] in the study conducted in Berlin (Germany) on three building facades found that the daily sap flow was influenced by incoming shortwave radiation, air temperature and relative humidity, but that the first was the most influencing factor. Van de Wouw et al. [31] analysing two living wall systems in Eindhoven (Netherlands) showed a linear correlation between solar radiation and evapotranspiration and stated that the deviation from linear correlation was due to variations in other climatic factors, i.e. wind speed, air relative humidity and temperature.

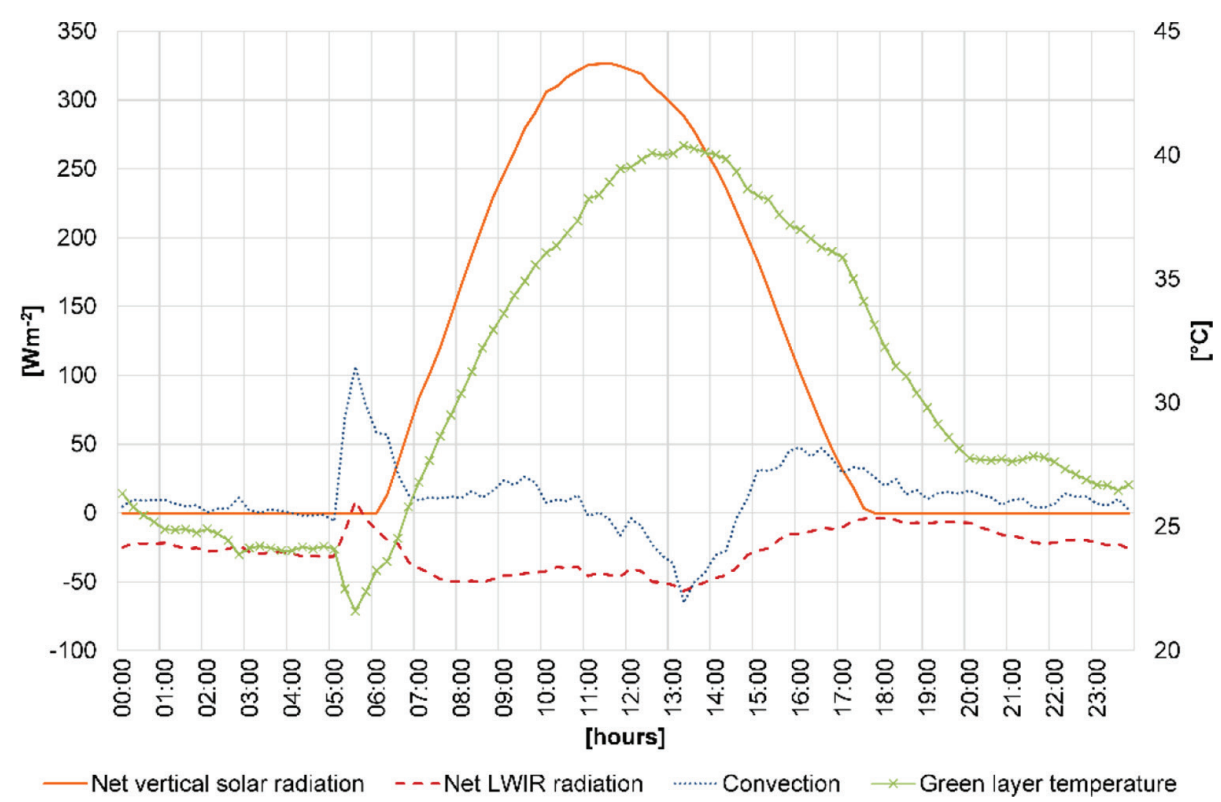

Figure 4: Net vertical solar radiation, net LWIR radiation and convection energy exchange for the green layer, measured green layer temperature (secondary axis), 17 September, 2015. 


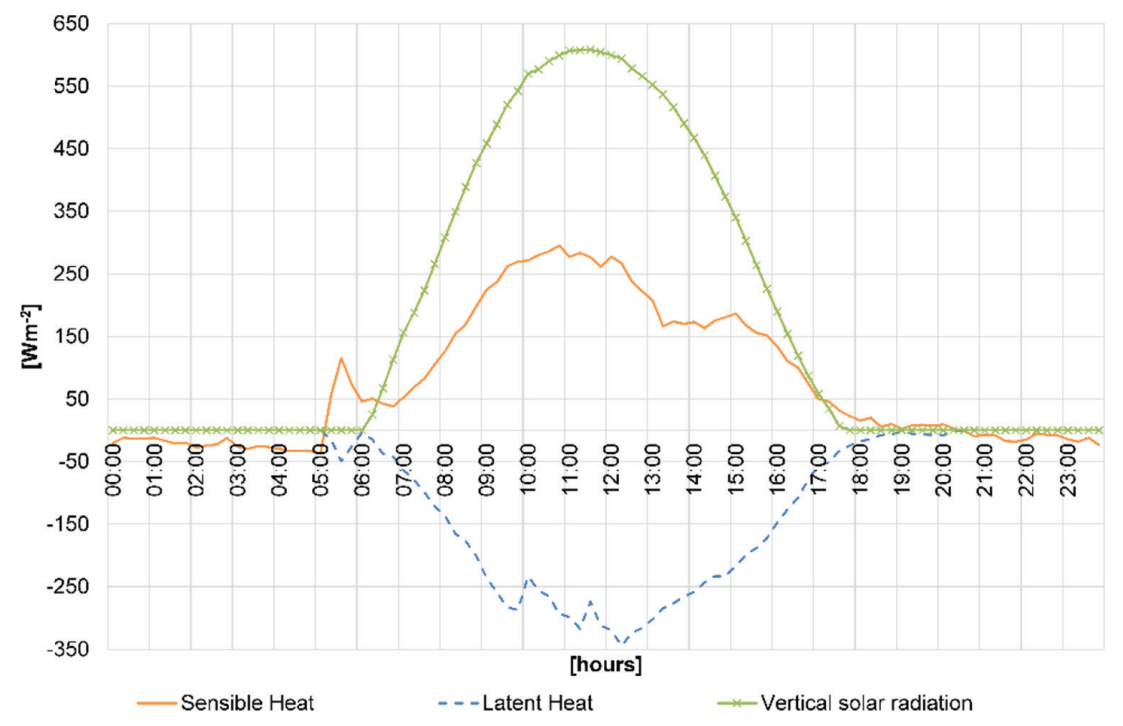

Figure 5: Sensible heat and latent heat exchange for the green layer, measured vertical solar radiation, 17 September, 2015.

\section{NOMENCLATURE}

\begin{tabular}{llll}
\hline $\mathrm{C}$ & heat transfer by conduction $\left[\mathrm{Wm}^{-2}\right]$ & $\mathrm{r}$ & resistance $\left[\mathrm{sm}^{-1}\right]$ \\
$\mathrm{C}_{\mathrm{pa}}$ & $\begin{array}{l}\text { specific heat of air at constant pressure } \\
{\left[\mathrm{Jkg}^{-1} \mathrm{~K}^{-1}\right]}\end{array}$ & $\mathrm{S}$ & heat storage $\left[\mathrm{Wm}^{-2}\right]$ \\
$\mathrm{CV}$ & heat transfer by convection $\left[\mathrm{Wm}^{-2}\right]$ & $\mathrm{T}$ & temperature $[\mathrm{K}]$ \\
$\mathrm{D}$ & thermal diffusivity $\left[\mathrm{m}^{2} \mathrm{~s}^{-1}\right]$ & $\mathrm{t}$ & time $[\mathrm{s}]$ \\
$\mathrm{E} \quad$ solar radiation $\left[\mathrm{Wm}^{-2}\right]$ & $\gamma$ & psychrometric constant $=66.7\left[\mathrm{PaK}^{-1}\right]$ \\
$\mathrm{e} \quad$ air vapour pressure $[\mathrm{Pa}]$ & $\varepsilon$ & emissivity $[\%]$ \\
$\mathrm{e}_{\mathrm{s}} \quad$ air vapour pressure at saturation $[\mathrm{Pa}]$ & $\rho$ & solar reflectivity $[\%]$ \\
$\mathrm{F}$ & view factor & $\rho_{a}$ & air density $\left[\mathrm{kgm}^{-3}\right]$ \\
$\mathrm{H}$ & heat transfer by ventilation $\left[\mathrm{Wm}^{-2}\right]$ & $\sigma$ & Stefan-Boltzmann constant \\
& & & $=5.6697 \mathrm{x} 10^{-8}\left[\mathrm{Wm} \mathrm{K}^{-2}\right]$ \\
$\mathrm{h}$ & convective coefficient $\left[\mathrm{Wm}^{-2} \mathrm{~K}^{-1}\right]$ & $\tau$ & solar transmissivity $[\%]$ \\
$\mathrm{Q}$ & heat exchanges for air conditioning $\left[\mathrm{Wm}^{-2}\right]$ & $\Phi$ & evapotranspiration $\left[\mathrm{Wm}^{-2}\right]$ \\
$\mathrm{R}$ & heat transfer by LWIR radiation $\left[\mathrm{Wm}^{-2}\right]$ & & \\
\hline
\end{tabular}

Subscripts

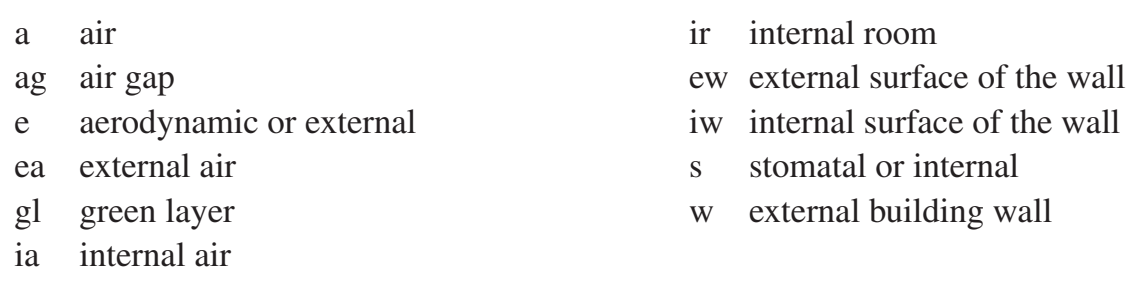




\section{CONCLUSIONS}

The study investigated the dynamics of heat transfer in the green facade and the energy balance of the elements that compose it. A heat balance equation was written for each layer.

The proposed energy balance considers all the thermal and physical processes: fluxes of shortwave radiation, longwave radiation, convection, conduction, heat storage and evapotranspiration. The study focuses its attention on the thermal behaviour of the green layer and on its energy balance. A specific objective is to understand the evapotranspiration trend with respect to all the other terms of the balance. The theoretical model was applied to measured data, recorded on an experimental green facade. The analysis of the single terms of the balance pointed out how their contributions influence the overall thermal balance of the green facade. The solar radiation is the most influencing parameter.

Overall, the developed model can be considered able to forecast the thermal behaviour of green facades. The obtained results could be implemented in models, simulating the building microclimate, to define useful tools specifically designed for green facades.

\section{ACKNOWLEDGEMENTS}

The contribution to programming and conducting this research must be equally shared between the Authors.

The present work has been carried out under the 'Piano triennale della Ricerca 2015-2017 nell' ambito del Sistema Elettrico Nazionale, Progetto D.1 'Tecnologie per costruire gli edifici del futuro', Obiettivo: Tecnologie "green" per gli edifici, Piano Annuale di Realizzazione (PAR) 2017', Accordo di Programma Ministero dello Sviluppo Economico - ENEA funded by the Italian Ministry of Economic Development.

\section{REFERENCES}

[1] Medl, A., Stangl, R. \& Florineth F., Vertical greening systems - A review on recent technologies and research advancement. Building and Environment, 125, pp. 227-239, 2017. https://doi.org/10.1016/j.buildenv.2017.08.054

[2] Safikhani, T., Abdullah, A.M., Ossen, D.R. \& Baharvand, M., A review of energy characteristic of vertical greenery systems. Renewable and Sustainable Energy Reviews, 40, pp. 450-462, 2014. https://doi.org/10.1016/j.rser.2014.07.166

[3] Manso, M. \& Castro-Gomes, J., Green wall systems: A review of their characteristics. Renewable and Sustainable Energy Reviews, 41, pp. 863-871, 2015. https://doi. org/10.1016/j.rser.2014.07.203

[4] Pérez, G., Coma, J., Martorell, I. \& Cabeza, L.F., Vertical Greenery Systems (VGS) for energy saving in buildings: A review. Renewable and Sustainable Energy Reviews, 39, pp. 139-165, 2014. https://doi.org/10.1016/j.rser.2014.07.055

[5] Bianco, L., Serra, V., Larcher, F. \& Perino, M., Thermal behaviour assessment of a novel vertical greenery module system: first results of a long-term monitoring campaign in an outdoor test cell. Energy Efficiency, 10(3), pp. 625-638, 2016. https://doi. org/10.1007/s12053-016-9473-4

[6] Santamouris, M., Cooling the cities - A review of reflective and green roof mitigation technologies to fight heat island and improve comfort in urban environments. Solar Energy, 103, pp. 682-703, 2012. https://doi.org/10.1016/j.solener.2012.07.003

[7] Schettini, E., Blanco, I., Scarascia Mugnozza, G., Campiotti, C.A. \& Vox, G., Contribution of green walls to building microclimate control. Proceedings of the 2 nd International Symposium on Agricultural Engineering (ISAE 2015), V-53-V-60, pp. 257-264, 2015. 
[8] Vox. G., Blanco, I. \& Schettini, E., Green facades to control wall surface temperature in buildings. Building and Environment, 129, pp. 154-166, 2018. https://doi.org/10.1016/j. buildenv.2017.12.002

[9] Schettini, E., Blanco, I., Campiotti, C.A., Bibbiani, C., Fantozzi, F. \& Vox, G., Green control of microclimate in buildings. Agriculture and Agricultural Science Procedia, $\mathbf{8}$, pp. 576-582, 2016. https://doi.org/10.1016/j.aaspro.2016.02.078

[10] Cameron, R.W.F., Taylor, J.E. \& Emmett, M.R., What's 'cool' in the world of green façades? How plant choice influences the cooling properties of green walls. Building and Environment, 73, pp. 198-207, 2014. https://doi.org/10.1016/j.buildenv.2013.12.005

[11] Norton, B.A., Coutts, A.M., Livesley, S.J., Harris, R.J., Hunter, A.M. \& Williams, N.S.G., Planning for cooler cities: A framework to prioritise green infrastructure to mitigate high temperatures in urban landscapes. Landscape and Urban Planning, 134, pp. 127-138, 2015. https://doi.org/10.1016/j.landurbplan.2014.10.018

[12] Raji, B., Tenpierik, M.J. \& Van Den Dobbelsteen, A., The impact of greening systems on building energy performance: A literature review. Renewable and Sustainable Energy Reviews, 45, pp. 610-623, 2015. https://doi.org/10.1016/j.rser.2015.02.011

[13] Jim, C.Y. \& He, H., Estimating heat flux transmission of vertical greenery ecosystem. Ecological Engineering, 37(8), pp. 1112-1122, 2011. https://doi.org/10.1016/j.ecoleng.2011.02.005

[14] Bowler, D.E., Buyung-Ali, L., Knight, T.M. \& Pullin, A.S., Urban greening to cool towns and cities: A systematic review of the empirical evidence. Landscape and Urban Planning, 97(3), pp. 147-155, 2010. https://doi.org/10.1016/j.landurbplan.2010.05.006

[15] Wong, N.H., Kwang Tan, A.Y., Chen, Y., Sekar, K., Tan, P.Y., Chan, D., Chiang, K. \& Wong, N.C., Thermal evaluation of vertical greenery systems for building walls. Building and Environment, 45(3), pp. 663-672, 2010. https://doi.org/10.1016/j.buildenv.2009.08.005

[16] Coma, J., Pérez, G., de Gracia, A., Burés, S., Urrestarazu, M. \& Cabeza, L.F., Vertical greenery systems for energy savings in buildings: A comparative study between green walls and green facades. Building and Environment, 111, pp. 228-237, 2017. https:// doi.org/10.1016/j.buildenv.2016.11.014

[17] Campiotti, C.A., Schettini, E., Alonzo, G., Viola, C., Bibbiani, C., Scarascia Mugnozza, G., Blanco, I. \& Vox, G., Building green covering for a sustainable use of energy. Journal of Agricultural Engineering, 44(2s), pp. 253-256, 2013. https://doi.org/10.4081/ jae.2013.292

[18] Pérez, G., Rincón, L., Vila, A., González, J.M. \& Cabeza, L.F., Green vertical systems for buildings as passive systems for energy savings. Applied Energy, 88(12), pp. 4854-4859, 2011. https://doi.org/10.1016/j.apenergy.2011.06.032

[19] Perini, K., Ottelé, M., Fraaij, A.L.A., Haas, E.M. \& Raiteri, R., Vertical greening systems and the effect on air flow and temperature on the building envelope. Building and Environment, 46(11), pp. 2287-2294, 2011. https://doi.org/10.1016/j.buildenv.2011.05.009

[20] Vox, G., Blanco, I., Campiotti, C.A., Giagnacovo, G. \& Schettini, E., Vertical green systems for buildings climate control. Proceedings of the 43rd International Symposium - Actual Tasks on Agricultural Engineering, Sveučilište u Zagrebu, Agronomski fakultet, Zavod za mehanizaciju poljoprivrede. Opatija, Croatia, 24-27/02/2015, pp. 723-732, 2015.

[21] Djedjig, R., El Ganaoui, M., Belarbi, R. \& Bennacer, R., Thermal effects of an innovative green wall on building energy performance. Mechanics \& Industry, 18(1), p. 104, 2017. https://doi.org/10.1051/meca/2016015 
[22] Vox, G., Blanco, I., Fuina, S., Campiotti, C.A., Scarascia Mugnozza, G. \& Schettini, E., Evaluation of wall surface temperatures in green facades. Proceedings of the Institution of Civil Engineers - Engineering Sustainability, 170(6), pp. 334-344, 2017. https://doi. org/10.1680/jensu.16.00019

[23] Susorova, I., Angulo, M., Bahrami, P. \& Stephens, B., A model of vegetated exterior facades for evaluation of wall thermal performance. Building and Environment, 67, pp. 1-13, 2013. https://doi.org/10.1016/j.buildenv.2013.04.027

[24] Kontoleon, K.J. \& Eumorfopoulou, E.A., The effect of the orientation and proportion of a plant-covered wall layer on the thermal performance of a building zone. Building and Environment, 45(5), pp. 1287-1303, 2010. https://doi.org/10.1016/j.buildenv.2009.11.013

[25] Flores Larsen, S., Filippín, C. \& Lesino, G., Modeling double skin green facades with traditional thermal simulation software. Solar Energy, 121, pp. 56-67, 2015. https://doi. org/10.1016/j.solener.2015.08.033

[26] Wong, N.H., Tan, A.Y.K., Tan, P.Y. \& Wong, N.C., Energy simulation of vertical greenery systems. Energy and buildings, 41(12), pp. 1401-1408, 2009. https://doi. org/10.1016/j.enbuild.2009.08.010

[27] Ip, K., Lam, M. \& Miller, A., Shading performance of a vertical deciduous climbing plant canopy. Building and Environment, 45(1), pp. 81-88, 2010. https://doi. org/10.1016/j.buildenv.2009.05.003

[28] Allen, R.G., Pereira, L.S., Raes, D. \& Smith, M., Crop evapotranspiration - guidelines for computing crop water requirements, FAO, 1998.

[29] Malys, L., Musy, M. \& Inard, C., A hydrothermal model to assess the impact of green walls on urban microclimate and building energy consumption. Building and Environment, 73, pp. 187-197, 2014. https://doi.org/10.1016/j.buildenv.2013.12.012

[30] Scarpa, M., Mazzali, U. \& Peron, F., Modeling the energy performance of living walls: Validation against field measurements in temperate climate. Energy and Buildings, 79, pp. 155-163, 2014. https://doi.org/10.1016/j.enbuild.2014.04.014

[31] Van de Wouw, P.M.F., Ros, E.J.M. \& Brouwers, H.J.H., Precipitation collection and evapotranspiration of living wall systems: A comparative study between a panel system and a planter bow system. Building and Environment, 126, pp. 221-237, 2017. https://doi.org/10.1016/j.buildenv.2017.10.002

[32] Kimball, B.A., Simulation of the energy balance of a greenhouse. Agricultural Meteorology, 11, pp. 243-260, 1973. https://doi.org/10.1016/0002-1571(73)90067-8

[33] Kindelan, M., Dynamic modelling of greenhouse environment. Transaction of the ASAE, 23(5), pp. 1232-1239, 1980. https://doi.org/10.13031/2013.34752

[34] Papadakis, G., Frangoudakis, A. \& Kyritsis, S., Experimental investigation and modelling of heat and mass transfer between a tomato crop and the greenhouse environment. Journal of Agricultural Engineering Research, 57(4), pp. 217-227, 1994. https://doi. org/10.1006/jaer.1994.1022

[35] Monteith, J.L. \& Unsworth, M., Principles of Environmental Physics, Edward Arnold: Great Britain, 1973.

[36] Hoelscher, M.T., Nehls, T., Jänicke, B. \& Wessolek, G., Quantifying cooling effects of façade greening: Shading, transpiration and insulation. Energy and Building, 114, pp. 283-290, 2016. https://doi.org/10.1016/j.enbuild.2015.06.047 